\title{
Comparative study of learning styles of college students
}

\section{Estudio comparativo de los estilos de aprendizaje del estudiante universitario}

\author{
CEPEDA-GONZÁLEZ, María Cristina †*, VILLARREAL-SOTO, Blanca Margarita, SÁNCHEZ- \\ RIVERA, Lilia and LUNA-ESPERICUETA, Samantha Sarahí
}

Universidad Autónoma de Coahuila, Mexico.

ID $1^{\text {st }}$ Author: María Cristina, Cepeda-González / ORC ID: 0000-0001-9468-2599, Researcher ID Tomson: T-14042018, CVU CONACYT ID: 613195

ID $1^{\text {st }}$ Co-author: Blanca Margarita, Villarreal-Soto / ORC ID: 0000-0001-9314-8001, Researcher ID Tomson: 23572018, CVU CONACYT ID: 947979

ID $2^{\text {nd }}$ Co-author: Lilia, Sánchez-Rivera / ORC ID: 0000-0003-0676-2412, Researcher ID Thomson: T-1651-2018, CVU CONACYT ID: 567204

ID $3^{\text {rd }}$ Co-author: Samantha Sarahí, Luna-Espericueta / ORC ID: 0000-0003-0501-0809, CVU CONACYT ID: 1150985

DOI: $10.35429 / J H S .2021 .14 .5 .1 .9$

Received July 10, 2021; Accepted December 30, 2021

\begin{abstract}
The research approach of this article was to observe which were the main differences of opinions between the groups and their learning styles, the methodology used was quantitative, observational, descriptive and comparative. A standardized ILP-R instrument was used, evaluates four complementary dimensions related to learning styles and processes in academic study that we will comment on later: (Deep Processing, Methodical Study, Retention of Facts and Elaborative Processing).with a sample of 1412 university students; the statistical analyzes that were carried out were descriptive and comparative. The main conclusion of the study is that students with an average of 90 percent develop an interest in continuing to learn and discover not only academically but personally, they are more expressive to people, they tend to make minimum mistakes because they have confidence in everything they do, Likewise, if the student works while studies , that provides an ability to relate to others, but dedicating solely to study allows more space to enjoy daily learning and full dedication to academic growth.
\end{abstract}

\section{Resumen}

El planteamiento de la investigación del presente artículo fue observar cuales fueron las principales diferencias de opinión entre los grupos y sus estilos de aprendizaje, la metodología que se utilizo fue cuantitativa, observacional, descriptiva y comparativa. Se utilizo un instrumento estandarizado ILP-R, instrumento que evalúa cuatro dimensiones complementarias relativas a los estilos y procesos de aprendizaje en el estudio académico que comentaremos posteriormente: (Procesamiento Profundo, Estudio Metódico, Retención de Hechos y Procesamiento Elaborativo). Con una muestra de 1412 estudiantes universitarios; los análisis estadísticos que se llevaron a cabo fueron el descriptivo y comparativo. La principal conclusión del estudio es que los estudiantes con un promedio de 90 desarrollan interés por seguir aprendiendo y descubriendo no solo académicamente si no personalmente, se muestran más expresivos a la gente, tienden un mínimo a equivocarse pues tienen confianza en todo lo que hacen, así mismo referente a que sí el estudiante trabajo mientras se está estudiando brinda una capacidad de relacionarse con los otros, pero el dedicarse únicamente al estudio permite mayor espacio a disfrutar del aprendizaje diario y a la dedicación plena del crecimiento académico.

Comparativo, Estilos, Aprendizaje

\footnotetext{
* Correspondence of the Author (Email: m_cepeda@uadec.edu.mx)

$\dagger$ Researcher contributing as first author.
} 


\section{Introduction}

Learning styles have become a very recurring and important theme throughout the history of human development, especially when we talk about education. These styles have accompanied each person on their educational path, from childhood to even old age, the antecedents generally define learning styles as traits that identify each subject in their process of understanding new knowledge. Recent research talks about the importance of studying learning styles since it is a way of understanding and understanding the student, this allows adapting techniques, methods or guiding them to achieve knowledge

In general, learning styles should provide and be the area of opportunity to strengthen the academic performance of students, especially when talking about higher education, since guidance is necessary to achieve significant results. This also allows us to see a diversity of styles that education encompasses, how people have their own qualities and aptitudes, which may have similarities, but differences such as the execution of these.

This research was done from the learning styles axis and its dimensions such as self-affirmation, elaborative processing and random response scale that make up the Schmeck instrument, this standardized questionnaire was applied to higher level students. The present work has the purpose of generating even greater interest in the study of learning styles and their variants for application within the classroom and that contributes to personal and academic development.

The relevance of this research lies in the integration of learning styles with all the dimensions covered according to Schmeck and their application in today's everyday life. In our reality, education is being around the student and their needs, their concerns, how they learn, their skills, their attitudes and skills.
For this reason, from this work, university students will benefit, as well as teachers themselves, since they will be given tools to make the acquisition of learning a natural and effective act within the classroom and outside of the classroom. allowing optimal school development to achieve academic improvement, likewise the achievement of a healthy and peaceful coexistence within school institutions.

Its theoretical value is based on the research that lies in the integration of theories that explain about the phenomenon of study to provide a foundation. The methodological value consists of the application of a standardized ILP-R instrument (Shmeck), this being an instrument that evaluates four complementary dimensions related to learning styles and processes in academic study that we will comment later: (Deep Processing, Methodical Study, Retention of Facts and Elaborative Processing). for its application and data collection. The viability of this project lies in access to the population for data collection, likewise within the theory there is an extensive and wide range of authors and articles that support the research.

The research approach is: -What are the main differences and opinion between the groups and their learning styles

With the following specific objectives:

What are the differences of opinion between men and women regarding selfassertion, Elaborative Processing, and Random Responses.

- What are the differences of opinion of the population that has an average of 90 and 80 regarding self-assertion.

What are the differences of opinion of the working population and the non-working population regarding elaborative thinking.

- What are the differences of opinion of the population that worked previously and those that did not regarding self-assertion.

What are the differences of opinion of the population that studies the degrees in Educational Sciences and Psychology regarding the scale of random responses. 


\section{Learning styles}

With regard to the research carried out by (Ramos Rodriguez, Rios, \& Gariboto, 2019), which has a quasi-experimental quantitative cut with a sample of master's and doctoral students in two different groups, the first one corresponding to participants in the Computer Tools for Research course, in the group two students from the Educational Platforms course. The results are taken that show that the learning states in addition to how the subjects learn, these are determined by biological relationships that can refer to the age, the development of the person and their physiological condition. Another remarkable result is that there are cognitive and personal relationships such as emotional states, the immersion environment that serve as an indicator to identify the predominance of a particular style, that is, the strategies that individuals assume to receive, organize and process information.

Abel Pérez, Cristian Méndez, Pedro Pérez and Héctor Yris in (2019), in the research article "Learning styles as a strategy for teaching in higher education" which has a mixed design (qualitative and quantitative) and a sample of 33 people, published in the Learning Styles Magazine, in this article we find that: Exploring learning styles will allow us to know how a student learns, which can serve as a starting point towards contextualized planning of activities. so as not to design teaching activities focused solely on the interest and style of the teacher. Not all teachinglearning techniques can be used as a generalization for all learning styles. Also, the types of curricular content to be learned must be considered.

\section{Learning Styles in Relation to Academic Performance}

In the research they carried out (Gonzalez, Saez, \& Ramirez, 2016) it is an exploratory and comparative study of the learning styles of the data collected by the CHAEA and the grades of the students, which was available to 213 firstyear Nursing students. semester.
From the conclusions of this, highlights the proposal of the application of teaching methodologies that stimulate the active participation of the student, leadership, autonomy, critical thinking and oral and written expression are considered optimizable. Similarly, it is suggested that, in order to obtain better performance, teachers know the learning styles of students and design pedagogical tools to promote learning styles and that students become aware of their own style. Since, as mentioned in the conclusions section, one of the ways to improve performance would be to promote teamwork based on the free association of students with different learning styles.

Juárez, Rodríguez, Escoto and Luna (2016), cited in (Polo \& Pereira, 2019), studied the relationship between learning styles, teaching strategies and academic performance in university students in Mexico. The CHAEA questionnaire was used to identify the learning styles and the CEVEAPEU questionnaire for teaching strategies. The results of this research indicate that theoretical and reflective students obtained better academic results than active and pragmatic students.

(Alducin-Ochoa \& Vázquez-Martínez, 2017), determined the dominant learning style of the students of the first year of Building Engineering (University of Seville), the influence of the style in the grades of each subject and if the style is affected by certain socio-demographic variables. The sample consisted of 161 students who answered the Honey Alonso questionnaire (CHAEA) and the CDAT. The descriptive and correlational methods have been used. For the data analysis, a univariate descriptive study was used, the one-way ANOVA, as well as the nonparametric Mann-Whitney and Kruskal-Wallis $\mathrm{U}$ tests, all of them with a confidence level of $95 \%(\alpha=.05)$. The results show a predominance of the reflective style, and that the grades according to the styles are variable between the subjects. No significant differences were found in the gender variables. 
On the research of (Carrascos Cifuentes \& Gonzalez Mendez, 2018) which is a quantitative study of cross-sectional design in which the sample consisted of 164 students, of which 113 correspond to women and 51 to men, for which the used the Honey-Alonso Learning Styles questionnaire (CHAEA).

One of the main results observed was that the active style was negatively correlated with performance, which indicated that the students with higher academic performance had lower scores in the active style, seen in another way, being an entertainer, improviser, risky, spontaneous, living in search of new experiences, among others, are characteristics that negatively affected the academic performance of students.

(Fonseca, Salcedo, \& Rocha, 2018), analyzed the relationship between styles and learning strategy with academic performance in internal and external evaluations in the Natural Sciences component. Seventy eleventh grade students were selected for the 2016 academic period. The techniques used were: the Felder Learning Styles measurement questionnaires, abbreviated version (2004) and ACRA Learning Strategies, abbreviated version (2003), the academic and the result of the Saber $11^{\text {th }}$ tests in the Natural Sciences component academic period 2016. The quantitative approach was used, framed in the positivist paradigm. The results of this work show the importance of knowing the students and thus implementing media pedagogical strategies for the proper development of knowledge in the area of Natural Sciences.

\section{Learning Styles Relating to Gender}

(Acevedo, Cavadia, \& Alvis, 2015), analyzed the learning styles in students of the Faculty of Engineering of the University of Cartagena. The sample consisted of 144 students, 72 women and 72 men of average age 22 years. The Honey-Alonso questionnaire on learning styles was applied to identify the active, reflective, theoretical and pragmatic behavior of the students. For this, a bifactorial analysis of variance and a Pearson correlation $(p \leq 0.05)$ were performed. The predominant style was reflective, with $31.9 \%$ of men and $36.1 \%$ of women in this category. There were no significant differences by gender $(p>0.05)$.
In men there was a direct correlation between reflective and pragmatic $(p<0.05)$ and in women an inverse relationship was found between active and theoretical $(\mathrm{p}<0.05)$.

It is observed in one of its many results that from the sample grouped by the gender variable, it can be observed that both (both female and male) have a moderate preference for Active, Reflective, Theoretical and Pragmatic Learning Styles; the Reflective style in the masculine gender has a low preference with a tendency to moderate.

In the research carried out by (Reyes Meza, Avila Rosales, Andrade Torres, \& Alcivar Cedeño, 2019), which is defined as field research, with the application of the chaea questionnaire to 300 high school students from the educational units of Chone present in 150 men and 150 women.

Among its predominant results, it is highlighted that the learning styles between diverse tasks that characterize men and women are recurrent, although reflective predominates in both genders, it is noted that men are more reflective than women, however women are more pragmatic than men, which indicates that men are more observant and women are more active and practical, showing that they are more applied than men when developing a task.

With regard to the research of (Tobon and Trujillo, 2019), which was carried out through a quantitative study, in which a random sample of 138 students belonging to the Faculty of Administrative and Economic Sciences was used, through of the Honey-Alonso CHAEA Learning Styles questionnaire which consists of 80 questions.

One of its main conclusions is that both the university women and men in this study share a reflective style in their way of learning, this type of learning is characterized as conscientious, receptive and analytical, additionally, the men are thinkers, disciplined and ordered due to their complementary learning style which is the theoretical one. 
The factorial validity, both global and between them, showed that the structure proposed by Schmeck (1991) is maintained with the small logical differences in any type of experimental replication and that the data on the reliability of the instrument have been higher than those obtained in its day. by the authors themselves, which could be explained by the different sample size used.

\section{Schmeck Learning Styles}

Several studies over time have tried to determine the way in which people conduct learning. Various authors have pointed out different approaches to the subject, which has led to the formulation of various theories on the aspects that affect the way people learn.

Understanding this variety of studies will facilitate the deepening of the subject since it will be easier to build on this work.

For Schmeck, (1982), on the other hand, a learning style, "is simply the cognitive style that an individual manifests when faced with a learning task, and reflects the preferred, habitual and natural strategies of the student to learn.

Schmeck (1982) defines three learning styles, each of which involves the use of a particular learning strategy by the student:

Depth style: typical of the student who uses the conceptualization strategy, which means that when he studies, he abstracts, analyzes, relates and organizes the abstractions (a facilitating strategy for high-level learning); Elaboration style: which implies the use by the student of a personalized strategy. For this student, the study content must be directly related to himself, to his experiences, to what has happened or he thinks will happen (facilitating strategy for medium-level learning); and Superficial style: which implies the use of a strategy focused on memorization; the student only remembers the content he / she reviewed while studying (a low-level learning facilitation strategy).
In other words, the deep style is typical of students who adopt the following strategies: conceptualization. By studying, you can abstract, analyze, relate, and organize abstraction (a strategy that promotes advanced learning). While the elaborative style means using individualized strategies. For this, the student and the learning content must be directly related to him. He himself, his experience, what happened or what he thought would happen are strategies to promote intermediate level learning in students. Finally, in the superficial style, this means using strategies that focus on memory, only students remember what they have seen while studying.

\section{Methodology}

Since the establishment of the question that serves as a primary part of the research was carried out, a search is carried out on the bibliography that bases and supports the main proposal of this research work; the general objective, the specific objectives, the research questions and hypotheses are developed, which coincide and are formed with the simple and complex variables of the instrument that is used.

Based on the previously established criteria, the sample with which it was worked was determined, indicating its application to 1412 people, being students of higher education, to facilitate the application it was modified digitally due to current social conditions. Therefore, the application of the instrument was applied through Google Forms.

The instrument is made up of two sections, the first one locates the general data of the variables such as: Age, Gender, City where you study, State where you study, Educational institution, Career, Study mode, Average, Currently working, Has worked with anteriority; Another section corresponds to the dimensions that complete the Learning Styles, some of them with a subdimension made up of 150 items measured using a scale from 1 to 6 . 
Once the data obtained has been organized in a concentration matrix, they are given the statistical treatment. The data were processed through a descriptive analysis that corresponds to frequencies and percentages, a comparative analysis through the Student's T test This research is quantitative, observational, descriptive and comparative.

\section{Results}

\section{Descriptive Analysis}

\section{Frequencies and Percentages}

An analysis of frequencies and percentages of the signal variables that represent the research sample is presented, the total of which corresponds to a value $n$ of 1412 subjects.

From the results, it is observed that $64.38 \%(\mathrm{n}=909)$ are women, while $35.06 \%$ (n $=495$ ) are men and $0.57 \%$ answered female, male $(n=8)$ and the age range ranges from 14 to 52 years, the ages with the greatest presence are 20 years whose value is $14.94 \%(n=211)$ and 21 years whose value is $17.42 \%(\mathrm{n}=246)$.

In addition, it is observed that of the total sample, $78.61 \%(\mathrm{n}=1110)$ are from the city of Saltillo and $92.35 \%(\mathrm{n}=1304)$ are from the State of Coahuila de Zaragoza.

It is observed that the educational institutions with the greatest presence are the Autonomous University of Coahuila with $46.32 \%(\mathrm{n}=654)$ and the Technological Institute of Saltillo with $8.57 \%(n=121)$ and the majors with the largest sample are Psychology with $11.69 \%(n=165)$, Bachelor of Education Sciences with $11.40 \% \quad(\mathrm{n}=161)$ and Industrial Engineering with $8 \%(\mathrm{n}=113)$ in terms of the modality that represents the sample is per semester with $77.76 \%(\mathrm{n}=1098)$. $15.79 \%(\mathrm{n}=223)$ of the sample have an average of 90 and $8.22 \%(n=116)$ have an average of 80 .

It is observed that $50.92 \%$ of the sample ( $n=719)$ do not currently work and $49.08 \%$ $(n=693)$ do. On the other hand, $80.24 \%$ $(\mathrm{n}=1133)$ report that they have worked before, while $19.76 \% \quad(\mathrm{n}=279)$ have not.

\section{Comparative Analysis}

\section{Student's $t$ for independent samples}

An analysis is presented in order to compare samples through their arithmetic means and find significant differences between groups of the sample studied with the Student's t test for independent samples with a probable error value less than 0.05 ( $\mathrm{p}<0.05)$. The statistical values that appear in this analysis are the values of the sample of each analysis group (Mean of the groups), the value of the t-test (t-value), the degrees of freedom (df) and the probability of the level error (p).

\section{Comparative Student's T Gender vs Self- affirmation, Elaborative Processing and Random Responses}

The reading in relation to the comparison between self-affirmation, elaborative processing and random response scale and the male and female genders reports that: It is observed that men are mostly not afraid to tell some authority what they disagree with, it is easy for them public speaking, they are more outgoing, they have not doubted the answers of a test compared to women.

Women have a greater interest in selfdevelopment, it is easy for them to remember words, they create systems to remember data while studying, they tend to create relationships of ideas, they believe that experience is important, for them life is a great adventure, they consider that Feelings are a very important part, they consider a person's point of view so important, they have a lot of interest in family values, they believe in intuition, ideas from books often make their mind wander and sometimes it seems to them I think with images and they have never failed a math test, all this compared to men.

It is inferred that men have a majority personal control to that of women, allowing them to establish relationships, make themselves known within social groups so they are not afraid to express themselves, showing that their degree of confidence and security in the things they do is high, unlike of women who exhibit lower-key, calmer qualities by spending time on academic and family issues. 
Comparative Student's T Average vs. Selfaffirmation, Elaborative Processing and Random Response Scale

In reading the comparison between selfassertion, elaborative processing and the random response scale against students who have an average of 90 and 80. It is observed that mostly students who have an average of 90 are not afraid to tell the people about their feelings, are primarily interested in selfdevelopment, develop study systems, consider experience so important, have a good imagination, ideas from books, often make their mind wander and never fail at anything they deal with to do compared to those with an average of 80 .

It is inferred that students with an average of 90 develop an interest in continuing to learn and discover not only academically but personally, they are more expressive to people, they tend to make mistakes a minimum because they have confidence in everything they do.

\section{Comparative Student's t-test You currently work vs Self-affirmation, Elaborative processing, Random response scale}

A reference between self-assertion, elaborative processing and the random response scale against students who currently work and those who do not. It is observed that students who work mostly do not find it difficult to speak in public, consider themselves as extroverts, do not doubt their performance in an exam and have never made a mistake in a math problem, while students who do not work They are mostly interested in self-development, remember words and ideas, believe that the experience is important, consider that life is an adventure and their feelings are important to them.It is inferred that work while studying provides an ability to relate to others, but dedicating yourself solely to study allows more space to enjoy daily learning and full dedication to academic growth.

\section{Comparative Student's t-test Previous work vs Self-affirmation, Elaborative processing and Random response scale}

Regarding the comparison between selfassertion, elaborative processing and the random response scale against students who worked previously and those who did not. It is observed that students who have not worked before prefer to sit and listen to others, make relationships to understand new ideas, consider that the experience is important, consider that life is an adventure, their feelings are an important part, for them the point of view of a person is important, they are interested in the values of the family, they have never had a bad math problem, compared to those who have worked who mostly find no problem speaking in public and consider themselves a person outgoing.

It is inferred that students who have not worked previously have more capacities to dedicate their time to their personal and academic growth, so they do not neglect their responsibilities and are able to have a balance in each task that they carry out, fulfilling them successfully.

Comparative Student's t University career vs Elaborative processing and Random response scale Likewise, the reading reports that, the comparison between the elaborative processing and the scale of random responses against the subjects who study the Bachelor of Psychology and those who study the Bachelor of Science in Education. It is observed that mostly psychology students when trying to understand new ideas, often relate them to old ideas compared to students of educational sciences.

It is inferred that students of the degree in educational sciences practice more mental agility, are quick to respond and analyze situations, this allows them to answer questionnaires with confidence and be assertive in their answers. 


\section{Conclusions}

According to the results obtained through the different statistical processes applied, this section presents the conclusions that respond to the specific objectives, previously raised according to the statistical levels with which we worked. Therefore, it is concluded that:

Men have greater personal control than women, allowing them to establish relationships, make themselves known within social groups, so they are not afraid to express themselves, showing that their degree of confidence and security in the things they do is high, unlike women They present calmer, lowkey qualities by spending time on academic and family issues.

It is also concluded that students with an average of 90 develop an interest in continuing to learn and discover not only academically but personally, they are more expressive to people, they tend to make mistakes a minimum because they have confidence in everything they do.

Regarding the fact that the student works while studying, it provides an ability to relate to others, but dedicating himself solely to study allows more space to enjoy daily learning and full dedication to academic growth.

In relation to the students who have not worked previously, it is concluded that they have more capacities to dedicate their time to their personal and academic growth, so they do not neglect their responsibilities and are able to have a balance in each task that they carry out by fulfilling them. successfully.

In turn, it is concluded that students of the degree in Education Sciences practice more mental agility, are quick to respond and analyze situations, this allows them to answer questionnaires with confidence and be assertive in their responses.

\section{References}

Acevedo, Cavadia, \& Alvis. (2015). Redalyc. Obtenido de Estilos de Aprendizaje de los Estudiantes de la Facultad de Ingeniería de la Universidad de Cartagena (Colombia): https://www.redalyc.org/articulo.oa?id=3735/3 73544191010
Alducin-Ochoa, \& Vázquez-Martínez. (2017). Redalyc. Obtenido de Estilos de aprendizaje, variables sociodemográficas y rendimiento académico en estudiantes de Ingeniería de Edificación:

https://www.redalyc.org/jatsRepo/1941/194150 012018/html/index.html

Carrascos Cifuentes , F. D., \& Gonzalez Mendez, M. A. (2018). Estilos de aprendizaje y rendimiento académico en estudiantes universitarios de Psicología en Talca. Revista Academica UCMaule, 127-128.

Domínguez, Gutiérrez, Llontop, Villalobos, \& Delva. (2015). ScienceDirect. Obtenido de Estilos de aprendizaje: un estudio diagnóstico en el centro universitario de ciencias económico-administrativas de la $\mathrm{U}$ de $\mathrm{G}$ : https://www.sciencedirect.com/science/article/p ii/S0185276015001053

Fonseca, Salcedo, \& Rocha. (2018). Estilos, estrategias de aprendizaje, relación desempeño académico, resultados pruebas saber $11^{\circ}$ en ciencias naturales, Colombia. ESPACIOS, 9.

Gonzalez, F., Saez , K., \& Ramirez , J. (2016). PERFILES DE ESTILOS DE APRENDIZAJE Y RENDIMIENTO ACADÉMICO EN ESTUDIANTES DE PRIMER AÑO DE ENFERMERÍA.

Juarez Lugo, C. S., Rodriguez Hernandez, G., Escoto Ponce de Leon, M. d., \& Luna Montijo, E. (2016). RELACIÓN DE LOS ESTILOS Y ESTRATEGIAS DE APRENDIZAJE CON EL RENDIMIENTO ACADÉMICO EN ESTUDIANTES UNIVERSITARIOS. Revista de Estilos de Aprendizaje.

Pérez Hernández, A. F., Méndez Sánchez, C. J., Pérez Arellano, P., \& Yris Whizar, H. M. (2019). Los estilos de aprendizaje como estrategia para la enseñanza en educación superior. Revista De Estilos De Aprendizaje, 12(23), 96-122. Recuperado a partir de http://revistaestilosdeaprendizaje.com/article/vi ew/1212

Ramos Rodriguez, N. Y., Rios, C. A., \& Gariboto, V. C. (2019). ESTILOS DE APRENDIZAJE Y ESTRATEGIAS PEDAGÓGICAS, UNA MIRADA AL CONTEXTO INTERNACIONAL. 
Reyes, Ávila, Andrade, \& Alcívar. (2019). Obtenido de NFLUENCIA DEL GÉNERO EN LOS ESTILOS DE APRENDIZAJE: https://www.uctunexpo.autanabooks.com/index .php/uct/article/view/170/215

Schmeck, R. (1982): Inventory of Learning Processes en "Students Learning Styles and Brain Behaivor", Ann Arbor, Michigan: ERIC. Ed., p. 80.

Tobon, L. M., \& Trujillo, G. (2019). ESTILOS DE APRENDIZAJES DE LOS ESTUDIANTES UNIVERSITARIOS. 28. 